\title{
Ultrasonographic evaluation of gastric content and volume: a systematic review
}

\author{
(D) César Antonio Tavares da Rocha' \\ (iD Lia Mayumi Kubota Kamada ${ }^{1}$ \\ (D) Pedro Hilton de Andrade Filho, \\ (iD) Isabela Araujo Villaverde ${ }^{2}$ \\ Dacqueline Yamahata Barbosa Shiro ${ }^{2}$ \\ (iD) Jão Manoel Silva Junior 3,4
}

\begin{abstract}
1. Hospital do Servidor Público Estadual de São Paulo, São Paulo, SP, Brasil. 2. Acadêmica de Medicina da Universidade Cidade de São Paulo, São Paulo, SP, Brasil. 3. Chefe do departamento de anestesiologia do Hospital do Servidor Público Estadual de São Paulo, São Paulo, SP, Brasil. 4. Programa de Pós-Graduação em Anestesiologia, Ciências Cirúrgicas e Medicina Perioperatória - FMUSP, São Paulo, Sp, Brasil.
\end{abstract}

http://dx.doi.org/10.1590/1806-9282.66.12.1725

\section{SUMMARY}

OBJECTIVE: Bronchoaspiration of gastric content is associated with high morbidity and mortality, but evaluating this complication is a difficult task. However, gastric ultrasonography can safely assess gastric content and prevent bronchoaspiration. Therefore, a systematic review was performed in order to verify the efficacy of ultrasonography in the qualitative and quantitative analyses of gastric content.

METHODS: A literature review of articles published between 2009 and 2019 in the PubMed and LILACS databases was conducted using combinations of the keywords "gastric ultrasound," "gastric emptying," and "gastric content."

RESULTS: Of the 20 articles found, 19 chose the antral region as the best site for qualitative analysis of the gastric content. Regarding quantitative measurement, the most commonly used method to calculate the gastric volume in eight articles was the formula "Gastric Volume $=27+(14.6 \times$ ATAG $)-(1.28 \times$ Age $), "$ in which the area of the transverse section of the gastric antrum (ATAG) could also be calculated by the largest antral diameters or by free tracing.

CONCLUSION: An efficient evaluation of the gastric content can be performed by ultrasonography of the antral region, contributing to greater safety in the clinical management of patients with increased risk for bronchoaspiration during airway management.

KEYWORDS: gastric ultrasonography, gastric content, gastric emptying

\section{INTRODUCTION}

Bronchoaspiration (BCA) of gastric content is a serious complication, and mortality increases with higher aspirated volumes or gastric content of $\mathrm{pH}<2.5$. $^{1}$ Adequate gastric emptying contributes to greater safety in procedures such as orotracheal intubation and endoscopic examinations, in which the incidence of BCA varies from $0.1-19 \%$, reaching mortality rates of $30 \%{ }^{2-4}$
Gastric content assessment is usually performed by invasive and/or high-cost techniques. Currently, the gold standard is gastric scintigraphy, which is a high-cost examination involving radiation exposure; hence, gastric ultrasonography (USG-G) is used as an alternative. ${ }^{5}$

Although there are reviews on the use of USG$G$, none evaluated the qualitative, quantitative, and 
risk analyses, and this review is the most recent. A literature review was performed to summarize the current knowledge about the assessment of gastric content by ultrasonography and measure the risk of perioperative BCA. This review aims to validate the methodology already described and evaluate its efficacy in determining the risk of complications in airway management.

\section{METHODS}

A systematic review was conducted in the CENTRAL (PubMed), MEDLINE (OvidSP), and EMBASE (OvidSP) databases for articles published between 2009 and 2019. The following keywords were used in the search: "antrum" or "gastric" and "sonography;" "antrum" or "gastric" and "ultrasound;" "antrum” or "gastric" and "emptying;" and "antrum" or "gastric" and "content." Studies involving the use of USG-G in humans were included when they contained specifications of the qualitative method of gastric content analysis (empty, clear, pasty, or solid-liquid), and/or method for quantification of gastric volume and/or volume considered as a risk for respiratory complications. Studies in animals and in special populations (pregnant women, children, obese, and diabetics) who present gastric motility different from the general population were excluded. The main purpose was to analyze the volume of gastric content (VCG) as a complication risk. In order to avoid bias in the selection of studies, two independent researchers conducted the search for the articles. After the initial selection, a discussion was held to define the most appropriate studies to be included in this review. For the articles to be considered, the following topics were observed: year of publication, the position of the patient during the examination, the portion of the stomach analyzed, existing gastric content, scanning technique, type of transducer, and type of research.

\section{RESULTS}

\section{Selected articles}

Initially, 426 articles were found, of which 20 were selected. The clinical trials included were evaluated for risk of bias, as shown in Figure 2, which resulted in a low to moderate risk in the selected articles.

The analyzed population included 1631 patients in several clinical settings such as emergency rooms $(n=39)$, intensive care units $(n=154)$, surgical procedures $(\mathrm{n}=921)$, and high digestive endoscopy procedures $(n=108)$, as well as healthy volunteers $(n=409)$.

\section{Anatomical portion}

The gastric antrum was the anatomical region of choice for gastric content evaluation in 19 studies.

FIGURE 1. FLOWCHART OF ARTICLE SELECTION

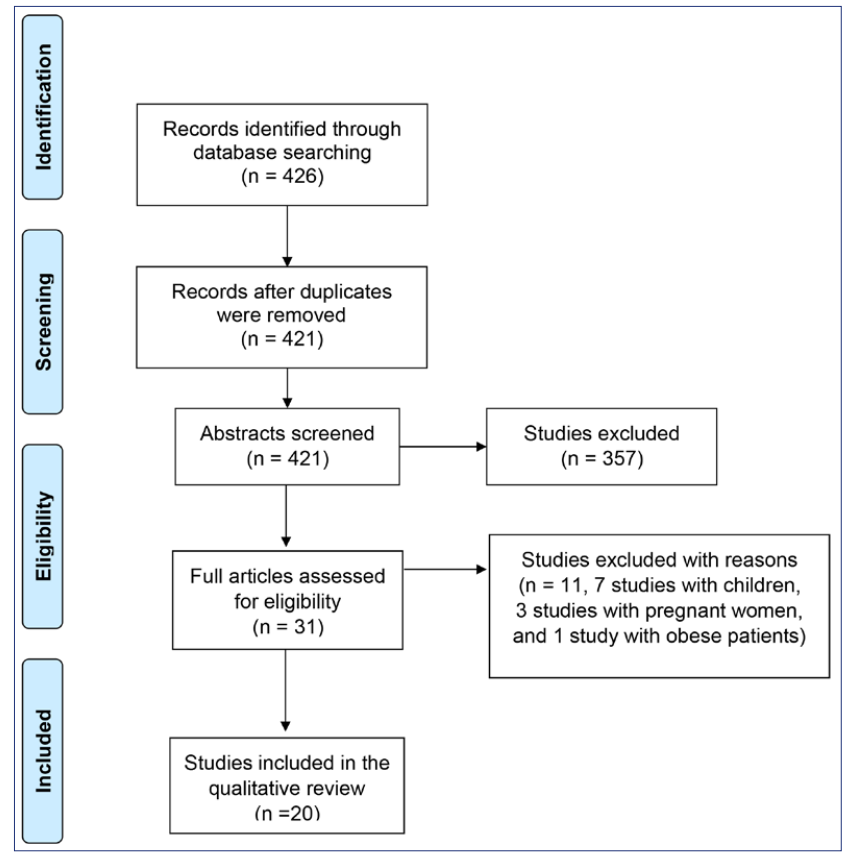

FIGURE 2. RISK OF BIAS ANALYSIS FOR CLINICAL TRIALS

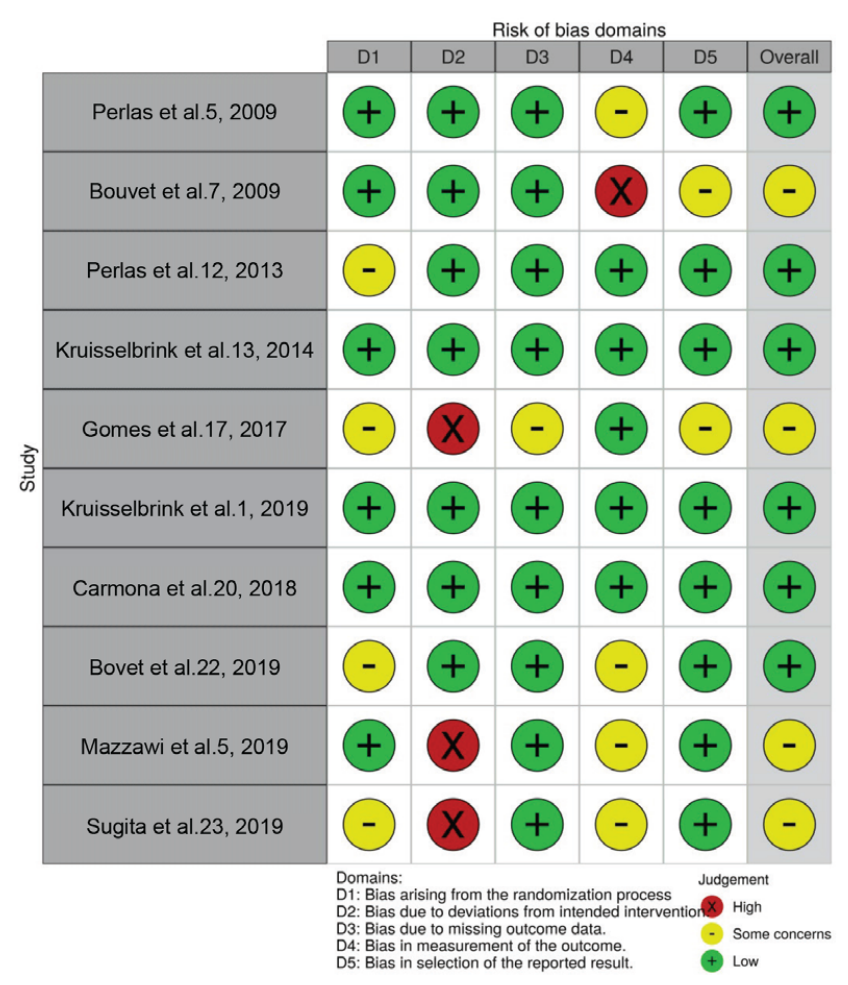




\section{Patient position}

The patients were most commonly in the supine and right lateral decubitus (DLD) positions. Twelve studies used the DLD position, either alone or associated with the supine position.

\section{Scanning and measures}

Nineteen studies recommended the use of low frequency (1-5 MHz) curvilinear transducers, and only one of them additionally used a high-frequency linear transducer (8-13 MHz).

To locate the gastric antrum, most studies recommended initiating parasagittal scanning in the left subcostal region. The probe was then slid to the right in search of the following anatomical references: the left lobe of the immediately cranial liver, used as a reference in 14 studies; the immediately posterior pancreas, used as a reference in seven studies; and the more deeply abdominal aorta, used as a reference in 10 studies. The other structures reported less frequently as anatomic references were the vena cava and superior mesenteric vein.

\section{METHODS OF GASTRIC CONTENT ANALYSIS Qualitative evaluation}

The evaluation of the type of gastric content was described in 11 articles, analyzed by differentiating between solid, liquid, and empty stomach contents. ${ }^{1,7-11,16,18-21}$

The imaging findings according to gastric content were as follows:
- Empty stomach: the gastric antrum was visualized with its walls juxtaposed with a "target" or "bull's eye" appearance (Figure 3A). ${ }^{6,11}$

- Liquid content: the distance from the antrum walls and filling of hypoechoic liquid content without residues was observed (Figure 3B). Immediately after ingestion or after a gastric contraction, the liquid content mixed with the air and formed a "star-filled sky" appearance (Figure 3C). Liquids with residues (e.g. milk or juices) showed a more echogenic content (Figure 3D). ${ }^{6,11}$

- Solid content: Solid food mixed with air, previous liquid, and gastric juices, formed a "frosted glass" appearance that could be accompanied by acoustic shading later (Figure 3E). After digestion, the gastric content presented a hyperechoic and more heterogeneous aspect, similar to that of hepatic parenchyma (Figure 3F).

A risk stratification model for the qualitative assessment of gastric content was proposed by Perlas, Davis: ${ }^{9}$ grade 0, empty gastric antrum in supine and DLD positions (suggesting empty stomach); grade 1, liquid content visualized only in DLD position (suggesting liquid in small quantity); and grade 2, liquid content visualized in supine and DLD positions (suggesting liquid in large quantity). It was observed that $75 \%$ of grade 1 patients had $<100 \mathrm{~mL}$ of gastric residue, $75 \%$ of grade 2 patients had $>100 \mathrm{~mL}$, and $50 \%$ of grade 2 patients had $>250 \mathrm{~mL} .^{9}$

FIGURE 3. ULTRASONOGRAPHY OF GASTRIC CONTENT IN THE RIGHT LATERAL DECUBITUS POSITION
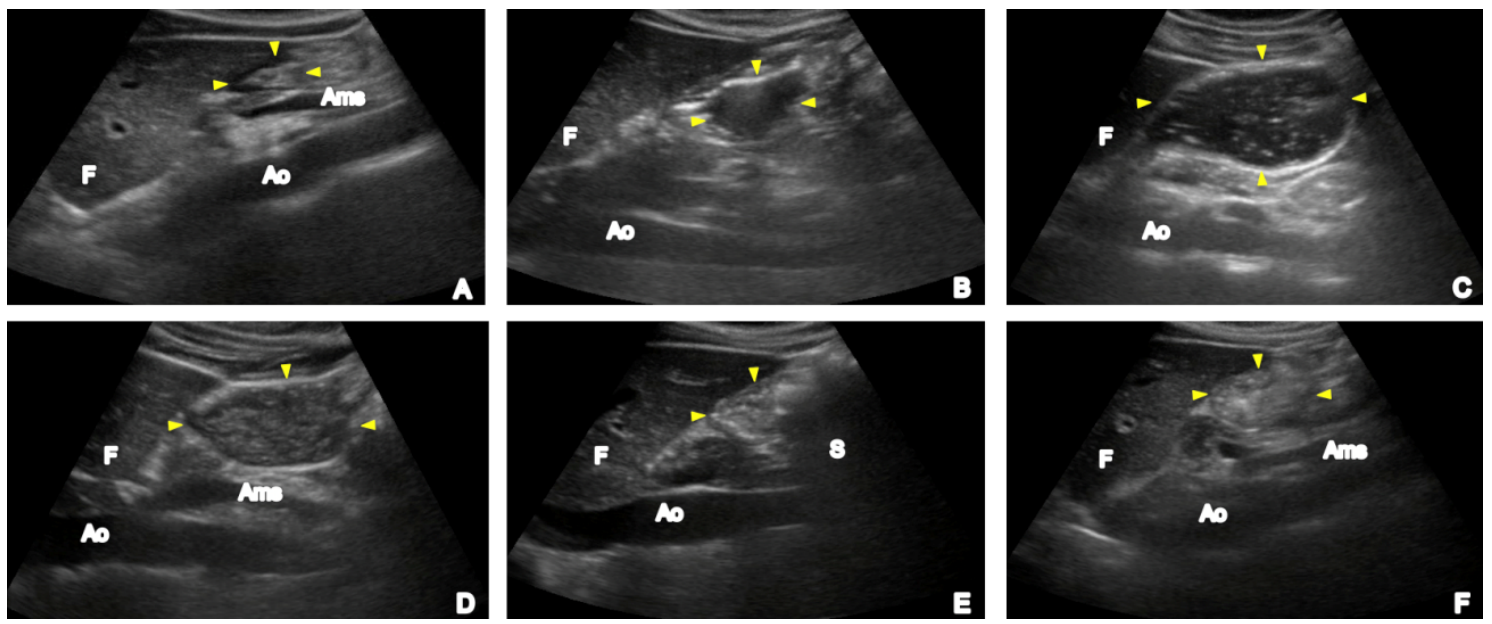

A: empty stomach; B: stomach with liquid without residues; C: stomach with liquid and air showing "sky of stars" appearance; D: stomach with liquid with residues; E: stomach with solids showing "frosted glass" appearance and acoustic shadow; F: stomach with solid late-stage digestion.

( $F=$ liver; $A m s=$ upper mesenteric artery; $A o=$ aorta; $S$ = posterior acoustic shadow; arrowheads = gastric antrum) 
TABLE 1. TECHNICAL ANALYSIS OF THE STUDIES

\begin{tabular}{|c|c|c|c|c|c|c|c|c|c|c|}
\hline Author & $\begin{array}{l}\text { Study } \\
\text { design }\end{array}$ & $\begin{array}{l}\text { Popu- } \\
\text { lation } \\
\text { studied }\end{array}$ & $\begin{array}{l}\text { Number of } \\
\text { partici- } \\
\text { pants }\end{array}$ & $\begin{array}{l}\text { Patient } \\
\text { position }\end{array}$ & $\begin{array}{l}\text { Stom- } \\
\text { ach } \\
\text { portion }\end{array}$ & Scanning & $\begin{array}{l}\text { Quantitative } \\
\text { Evaluation }\end{array}$ & $\begin{array}{l}\text { VCG risk } \\
\text { for BCA } \\
(\mathrm{mL} / \mathrm{kg})\end{array}$ & $\begin{array}{l}\text { Semi- } \\
\text { quantitative } \\
\text { evaluation }\end{array}$ & Probe \\
\hline Perlas, Chan ${ }^{6}$ & $\begin{array}{l}\text { Clinical } \\
\text { trial }\end{array}$ & Volunteers & $\begin{array}{l}\text { Stage 1: } 18 \\
\text { Phase 2: } 36\end{array}$ & Supine & $\mathrm{A} / \mathrm{C} / \mathrm{F}$ & Parasagittal & Yes & NA & NA & $\begin{array}{l}\text { Curvilinear } \\
\text { 2-5 } \mathrm{MHz}\end{array}$ \\
\hline $\begin{array}{l}\text { Bouvet, } \\
\text { Miquel }^{7}\end{array}$ & $\begin{array}{l}\text { Clinical } \\
\text { trial }\end{array}$ & Volunteers & 22 & Semi-sitting & Antrum & Sagittal & Yes & NA & NA & $\begin{array}{l}\text { Curvilinear } \\
2-5 \mathrm{MHz}\end{array}$ \\
\hline $\begin{array}{l}\text { Koenig, } \\
\text { Lakticova }^{8}\end{array}$ & $\begin{array}{l}\text { Obser- } \\
\text { vational }\end{array}$ & $\begin{array}{l}\text { ICU } \\
\text { patients }\end{array}$ & 80 & Supine & $C / F$ & $\begin{array}{l}\text { Sagittal and } \\
\text { parasagittal } \\
\text { in LAM }\end{array}$ & No & NA & NA & $\begin{array}{l}\text { Curvilinear } \\
1-5 \mathrm{MHz}\end{array}$ \\
\hline Perlas, Davis ${ }^{9}$ & $\begin{array}{l}\text { Obser- } \\
\text { vational }\end{array}$ & $\begin{array}{l}\text { Surgical } \\
\text { patients }\end{array}$ & 200 & Supine/DLD & Antrum & Sagittal & Yes & NA & Yes & $\begin{array}{l}\text { Curvilinear } \\
\text { 2-5 } \mathrm{MHz}\end{array}$ \\
\hline $\begin{array}{l}\text { Bouvet, } \\
\text { Mazoit }^{10}\end{array}$ & $\begin{array}{l}\text { Obser- } \\
\text { vational }\end{array}$ & $\begin{array}{l}\text { Surgical } \\
\text { patients }\end{array}$ & 183 & Semi-sitting & Antrum & Sagittal & Yes & $>0.8$ & NA & $\begin{array}{l}\text { Curvilinear } \\
2-5 \mathrm{MHz}\end{array}$ \\
\hline Cubillos, Tse ${ }^{11}$ & $\begin{array}{l}\text { Obser- } \\
\text { vational }\end{array}$ & Volunteers & 6 & DLD & Antrum & $\begin{array}{l}\text { Axial/Sag- } \\
\text { ittal }\end{array}$ & No & NA & NA & $\begin{array}{l}\text { Curvilinear } \\
\text { 2-5 } \mathrm{MHz} / \\
\text { linear 8-13 }\end{array}$ \\
\hline $\begin{array}{l}\text { Perlas, } \\
\text { Mitsakakis }{ }^{\mathbf{1 2}}\end{array}$ & $\begin{array}{l}\text { Clinical } \\
\text { trial }\end{array}$ & $\begin{array}{l}\text { EDA } \\
\text { patients }\end{array}$ & 108 & DLD & Antrum & Sagittal & Yes & $>1.5$ & Yes & $\begin{array}{l}\text { Curvilinear } \\
2-5 \mathrm{MHz}\end{array}$ \\
\hline $\begin{array}{l}\text { Kruisselbrink, } \\
\text { Arzola }{ }^{\mathbf{1 3}}\end{array}$ & $\begin{array}{l}\text { Clinical } \\
\text { Trial }\end{array}$ & Volunteers & 22 & Supine/DLD & Antrum & Sagittal & Yes & NA & NA & $\begin{array}{l}\text { Curvilinear } \\
\text { 2-5 } \mathrm{MHz}\end{array}$ \\
\hline $\begin{array}{l}\text { Hamada, } \\
\text { Garcon }^{\mathbf{1 4}}\end{array}$ & $\begin{array}{l}\text { Obser- } \\
\text { vational }\end{array}$ & $\begin{array}{l}\text { ICU } \\
\text { patients }\end{array}$ & 55 & Semi-sitting & Antrum & Sagittal & Yes & $>0.8$ & NA & $\begin{array}{l}\text { Curvilinear } \\
\text { 2-5 } \mathrm{MHz}\end{array}$ \\
\hline $\begin{array}{l}\text { Bisinotto, } \\
\text { Pansani }{ }^{15}\end{array}$ & $\begin{array}{l}\text { Obser- } \\
\text { vational }\end{array}$ & Volunteers & 67 & Supine/DLD & Antrum & Sagittal & Yes & $>1.5$ & NA & $\begin{array}{l}\text { Curvilinear } \\
\text { 2-5 } \mathrm{MHz}\end{array}$ \\
\hline $\begin{array}{l}\text { Sharma, } \\
\text { Gudivada }\end{array}$ & $\begin{array}{l}\text { Obser- } \\
\text { vational }\end{array}$ & $\begin{array}{l}\text { ICU } \\
\text { patients } \\
\text { (enteral } \\
\text { nutrition) }\end{array}$ & 19 & Semi-sitting & Antrum & Sagittal & Yes & $>500$ & NA & $\begin{array}{l}\text { Curvilinear } \\
2-5 \mathrm{MHz}\end{array}$ \\
\hline $\begin{array}{l}\text { Gomes, } \\
\text { Caporossi }{ }^{17}\end{array}$ & $\begin{array}{l}\text { Clinical } \\
\text { trial }\end{array}$ & Volunteers & 20 & DLD & Antrum & Sagittal & Yes & NA & NA & $\begin{array}{l}\text { Not In- } \\
\text { formed }\end{array}$ \\
\hline $\begin{array}{l}\text { Bisinotto, } \\
\text { Naves }\end{array}$ & $\begin{array}{l}\text { Obser- } \\
\text { vational }\end{array}$ & Volunteers & 80 & Supine/DLD & $\mathrm{A} / \mathrm{C}$ & Parasagittal & Yes & NA & Yes & $\begin{array}{l}\text { Curvilinear } \\
2-5 \mathrm{MHz}\end{array}$ \\
\hline $\begin{array}{l}\text { Van de Putte, } \\
\text { Vernieuwe }{ }^{19}\end{array}$ & $\begin{array}{l}\text { Obser- } \\
\text { vational }\end{array}$ & $\begin{array}{l}\text { Surgical } \\
\text { patients }\end{array}$ & 538 & Supine/DLD & Antrum & Sagittal & Yes & $>1.5$ & Yes & $\begin{array}{l}\text { Curvilinear } \\
2-5 \mathrm{MHz}\end{array}$ \\
\hline $\begin{array}{l}\text { Carmona, } \\
\text { Almeida }\end{array}$ & $\begin{array}{l}\text { Clinical } \\
\text { trial }\end{array}$ & Volunteers & 17 & DLD & Antrum & Sagittal & Yes & $>0.8$ & NA & $\begin{array}{l}\text { Curvilinear } \\
2-6 \mathrm{MHz}\end{array}$ \\
\hline $\begin{array}{l}\text { Kruisselbrink, } \\
\text { Gharapetian¹ }\end{array}$ & $\begin{array}{l}\text { Clinical } \\
\text { trial }\end{array}$ & Volunteers & 40 & Supine/DLD & Antrum & Sagittal & Yes & $>1.5$ & Yes & $\begin{array}{l}\text { Curvilinear } \\
2-5 \mathrm{MHz}\end{array}$ \\
\hline $\begin{array}{l}\text { Okada, } \\
\text { Toyama }\end{array}$ & $\begin{array}{l}\text { Obser- } \\
\text { vational }\end{array}$ & $\begin{array}{l}\text { Emergen- } \\
\text { cy patients }\end{array}$ & 39 & Supine & Antrum & Sagittal & Yes & $>1.5$ & NA & $\begin{array}{l}\text { Curvilinear } \\
2-5 \mathrm{MHz}\end{array}$ \\
\hline $\begin{array}{l}\text { Bouvet, } \\
\text { Barnoud } 22\end{array}$ & $\begin{array}{l}\text { Clinical } \\
\text { trial }\end{array}$ & Volunteers & 25 & $\begin{array}{l}\text { Semi-sitting } \\
\text { at } 0,30^{\circ} \text {, and } \\
45^{\circ} \text {, and DLD }\end{array}$ & Antrum & Sagittal & Yes & $>1.5$ & Yes & $\begin{array}{l}\text { Curvilinear } \\
2-5,5 \mathrm{MHz}\end{array}$ \\
\hline $\begin{array}{l}\text { Mazzawi, } \\
\text { Bartsch }^{5}\end{array}$ & $\begin{array}{l}\text { Clinical } \\
\text { trial }\end{array}$ & Volunteers & 32 & Sitting & Antrum & ND & Yes & NA & NA & $\begin{array}{l}\text { Curvilinear } \\
4 \mathrm{MHz}\end{array}$ \\
\hline $\begin{array}{l}\text { Sugita, } \\
\text { Matsumoto }\end{array}$ & $\begin{array}{l}\text { Clinical } \\
\text { trial }\end{array}$ & Volunteers & 24 & DLD & Antrum & Parasagittal & Yes & NA & NA & $\begin{array}{l}\text { Curvilinear } \\
2-5 \mathrm{MHz}\end{array}$ \\
\hline
\end{tabular}

DLD: right lateral decubitus; EDA: upper-digestive endoscopy; A: antrum; C: body; F: gastric fundus; ND: not described; NA: not evaluated; LAM: middle axillary line; VCG: volume of gastric content; BCA: bronchoaspiration; ICU: intensive care unit.

\section{Quantitative Evaluation}

Eighteen studies correlated the measurement of the area of the transverse section of the gastric antrum (ATAG) and the VCG. The ATAG measurement was calculated in two ways: measurement of the area by free tracing including the serous layer; and the technique used in 16 studies involving the anteroposterior (AP) and craniocaudal (CC) diameter measurements, measured from serous to serous by the formula: ATAG $=(\mathrm{CC} \times \mathrm{AP} \times \pi) / 4 .{ }^{24}$
A comparative study between these ATAG measurement techniques showed a small difference in the predicted VCG value of up to $20 \mathrm{~mL}$ in $96 \%$ of cases. ${ }^{13}$

Another study developed a mathematical model capable of estimating the VCG according to the measurement of ATAG in the DLD position using the age of the patient as the only covariable in the formula: VCG $(\mathrm{mL})=27+(14.6 \times$ ATAG $)-(1.28 \times$ age $)$. This mathematical model was used by eight of the studies analyzed., ${ }^{6,12}$ Okada Toyama, ${ }^{21}$ using computed tomography as the 
USG-G control group, showed that ATAG measurements $>3.01 \mathrm{~cm}^{2}$ in the supine position were indicative of either gastric content $>1.5 \mathrm{~mL} / \mathrm{kg}$ or presence of solid content, with a sensitivity of $85 \%$ and specificity of $53 \%$.

\section{Combined assessment and correlation with} bronchoaspiration risk

High-risk predictors for BCA include the presence of solid residues in any amount or large liquid content, defined as VCG $>1.5 \mathrm{~mL} / \mathrm{kg}$ in six analyzed studies. ${ }^{10,12}$

The main fasting management protocol and risk classification for BCA proposed by Van de Putte and Perlas ${ }^{25}$ advocate scanning in the supine and DLD positions and classifying BCA risk according to the USG-G findings as follows:

- Low risk: Empty antrum

- High risk: Solid waste

- Presence of liquid waste calculated by ATAG: After calculation, correlate the ATAG measurement with the VCG according to the formula: VCG $(\mathrm{mL})=27+14.6 \times \operatorname{ATAG}\left(\mathrm{cm}^{2}\right)-1.28 \times$ age (years). If VCG is $>1.5 \mathrm{~mL} / \mathrm{kg}$, it is considered high risk for $\mathrm{BCA}$, and if $<1.5 \mathrm{~mL} / \mathrm{kg}$, it is considered low risk.

\section{DISCUSSION}

This review found several studies using USG-G for qualitative and quantitative assessments of gastric content. Regarding the methodology, most of the articles opted for the analysis of the antral region, which has a better relationship with the measurement of gastric content and volume. Although a small divergence occurred in the image acquisition of the gastric antrum, all studies preferred sagittal/parasagittal scanning.

The antral ultrasound visualization is complicated by the presence of air and the depth of the anatomical structures, with the curvilinear transducer of low frequency (2-5 MHz) being the best to perform the exam.

The supine position followed by the DLD position seems favorable to measure the volume and classify the risk, since DLD not only allows better visualization of the antrum in its lower portion and a better correlation with ATAG as compared to the supine position but also provides greater sensitivity and specificity in the examination. ${ }^{11,22}$

The method of quantitative evaluation regarding the measurement technique and its accuracy, reliability, and reproducibility is still debatable. The measurement of ATAG through free tracing, though technically easier, still requires further studies for its validation, because it has only been used in two studies. ATAG measurement should be performed by involving the entire serous layer of the stomach and outside periods of peristaltic contractions. For greater accuracy of the test, it is recommended to use the mean of three ATAG measurements in clinical practice, since the mean of multiple measurements to calculate VCG has a good correlation with gastric scintigraphy measurements. ${ }^{26}$

Thus, USG-G could be an efficient method for airway management in cases of uncertain fasting, risk factors for gastric emptying delay, or unreliable history (cognitive dysfunction, delirium). ${ }^{14}$

This systematic review had the limitation of analyzing studies of different designs performed in controlled environments, single centers, and with homogeneous populations. Moreover, the number of selected articles may have been insufficient, despite the estimated time for the study to be conducted over 10 years. Therefore, studies with a larger scope are necessary to generalize these recommendations in other populations.

\section{CONCLUSION}

The bedside use of USG-G has been consolidated in clinical practice. Currently, the USG-G of the antral region is the most practical, non-invasive, and easy imaging method to characterize gastric content and volume.

\section{Author's Contribution}

César Antonio Tavares Da Rocha - conceptualization and design of the study, search and analysis of articles, writing of the original manuscript, elaboration and revision of the graphic components (tables and figures); Lia Mayumi Kubota Kamada - study design, search and analysis of articles, writing of the original manuscript, elaboration and revision of graphic components (tables and figures); Pedro Hilton de Andrade Filho - study design, review of the selected articles, elaboration and review of graphic components (tables and figures), review of the original manuscript, and writing of the final manuscript; Isabela Araujo Villaverde and Jacqueline Yamahata Barbosa Shiro review of the selected articles, preparation and review of graphic components (tables and figures), writing of the original manuscript; João Manoel da Silva Junior - conceptualization and design of the study, revision and orientation of methodology, revision of graphic components (tables and figures), revision of the original and final manuscripts. 


\section{RESUMO}

OBJETIVO: A broncoaspiração do conteúdo gástrico associa-se 'a alta morbimortalidade, porem a avaliação desta complicação é tarefa dificil. Por outro lado, a ultrassonografia gástrica avalia o conteúdo gástrico com segurança, podendo evitar a broncoaspiração. Portanto, foi realizada revisão sistemática com objetivo de verificar a aplicabilidade da ultrassonografia na análise qualitativa e quantitativa do conteúdo gástrico.

MÉTODOS: Revisão de literatura de artigos publicados entre 2009 e 2019 nas bases de dados PubMed e LILACS usando combinações das palauras chave: "Gastric ultrasound", "gastric emptying" e "gastric content".

RESULTADOS: Foram encontrados 20 artigos. A região antral foi escolhida em 19 artigos como melhor local do ponto de vista qualitativo para analisar o conteúdo gástrico. A respeito da mensuração quantitativa, o método mais utilizado para cálculo do volume gástrico, escolhido em 8 artigos, foi através da fórmula Volume gástrico = 27 + (14,6 $\times$ ATAG) - (1,28 x Idade), em que a Área da Secção Transversa do Antro Gástrico (ATAG) pode ser igualmente calculada pelos maiores diâmetros antrais ou pelo seu traçado livre.

CONCLUSÃo: A ultrassonografia da região antral permite boa avaliação do conteúdo gástrico, trazendo maior segurança ao manejo clínico de pacientess com risco aumentado para broncoaspiração no manejo da via aerea.

PALAVRAS CHAVE: Ultrassonografia gástrica, conteúdo gástrico, esvaziamento gástrico.

\section{REFERENCES}

1. Kruisselbrink R, Gharapetian A, Chaparro LE, Ami N, Richler D, Chan VWS, et al. Diagnostic accuracy of point-of-care gastric ultrasound. Anesth Analg 2019;128(1):89-95

2. Studer $P$, Räber G, Ott D, Candinas $D$, Schnüriger B. Risk factors for fatal outcome in surgical patients with postoperative aspiration pneumonia. Int | Surg. 2016;27:21-5.

3. Cameron JL, Mitchell WH, Zuidema GD. Aspiration pneumonia: clinical outcome following documented aspiration. Arch Surg. 1973;106(1):49-52.

4. Kozlow JH, Berenholtz SM, Garrett E, Dorman T, Pronovost PJ. Epidemiology and impact of aspiration pneumonia in patients undergoing surgery in Maryland, 1999-2000. Crit Care Med. 2003;31(7):1930-7.

5. Mazzawi T, Bartsch E, Benammi S, Ferro RMC, Nikitina E, Nimer N, et al. Gastric emptying of low- and high-caloric liquid meals measured using ultrasonography in healthy volunteers. Ultrasound Int Open. 2019;5(1):E27-E33.

6. Perlas A, Chan VW, Lupu CM, Mitsakakis N, Hanbidge A. Ultrasound assessment of gastric content and volume. Anesthesiology. 2009;111(1):82-9.

7. Bouvet L, Miquel A, Chassard D, Boselli E, Allaouchiche B, Benhamou D. Could a single standardized ultrasonographic measurement of antral area be of interest for assessing gastric contents? A preliminary report. Eur J Anaesthesiol. 2009;26(12):1015-9.

8. Koenig SJ, Lakticova V, Mayo PH. Utility of ultrasonography for detection of gastric fluid during urgent endotracheal intubation. Intensive Care Med. 2011;37(4):627-31.

9. Perlas A, Davis L, Khan M, Mitsakakis N, Chan VW. Gastric sonography in the fasted surgical patient: a prospective descriptive study. Anesth Analg. 2011;113(1):93-7.

10. Bouvet L, Mazoit JX, Chassard D, Allaouchiche B, Boselli E, Benhamou D. Clinical assessment of the ultrasonographic measurement of antral area for estimating preoperative gastric content and volume. Anesthesiology. 2011;114(5):1086-92.

11. Cubillos J, Tse C, Chan VW, Perlas A. Bedside ultrasound assessment of gastric content: an observational study. Can | Anaesth. 2012;59(4):416-23.

12. Perlas A, Mitsakakis N, Liu L, Cino M, Haldipur N, Davis L, et al. Validation of a mathematical model for ultrasound assessment of gastric volume by gastroscopic examination. Anesth Analg. 2013;116(2):357-63.

13. Kruisselbrink R, Arzola C, Endersby R, Tse C, Chan V, Perlas A. Intra- and interrater reliability of ultrasound assessment of gastric volume. Anesthesiology. 2014;121(1):46-51.

14. Hamada SR, Garcon P, Ronot M, Kerever S, Paugam-Burtz C, Mantz I. Ultrasound assessment of gastric volume in critically ill patients. Intensive Care Med. 2014;40(7):965-72.
15. Bisinotto FM, Pansani PL, Silveira LA, Naves AA, Peixoto AC, Lima HM et al. Qualitative and quantitative ultrasound assessment of gastric content. Rev Assoc Med Bras. 2017;63(2):134-41.

16. Sharma V, Gudivada D, Gueret R, Bailitz |. Ultrasound-assessed gastric antral area correlates with aspirated tube feed volume in enterally fed critically ill patients. Nutr Clin Pract. 2017;32(2):206-11.

17. Gomes PC, Caporossi C, Aguilar-Nascimento JE, Silva AM, Araujo VM. Residual gastric volume evaluation with ultrasonography after ingestion of carbohydrate- or carbohydrate plus glutamine-enriched beverages: a randomized, crossover clinical trial with healthy volunteers. Arq Gastroenterol. 2017; 54(1):33-6.

18. Bisinotto FMB, Naves AA, Lima HM, Peixoto ACA, Maia GC, Resende Junior PP, et al. Use of ultrasound for gastric volume evaluation after ingestion of different volumes of isotonic solution. Rev Bras Anestesiol. 2017;67(4):376-82.

19. Van de Putte $P$, Vernieuwe L, Jerjir A, Verschueren L, Tacken M, Perlas A. When fasted is not empty: a retrospective cohort study of gastric content in fasted surgical patients. $\mathrm{Br}$ | Anaesth. 2017;118(3):363-371.

20. Carmona BM, Almeida CCA, Vieira WB, Fascio MNC, Carvalho LR, Vane LA, et al. Ultrasound dynamics of gastric content volumes after the ingestion of coconut water or a meat sandwich. A randomized controlled crossover study in healthy volunteers. Rev Bras Anestesiol. 2018;68(6):584-90.

21. Okada $Y$, Toyama H, Kamata K, Yamauchi M. A clinical study comparing ultrasound-measured pyloric antrum cross-sectional area to computed tomography-measured gastric content volume to detect high-risk stomach in supine patients undergoing emergency abdominal surgery. J Clin Monit Comput. 2019. doi: 10.1007/s10877-019-00438-1.

22. Bouvet $L$, Barnoud S, Desgranges FP, Chassard D. Effect of body position on qualitative and quantitative ultrasound assessment of gastric fluid contents. Anaesthesia. 2019;74(7):862-7.

23. Sugita $M$, Matsumoto $M$, Tsukano $Y$, Fukunaga $C$, Yamamoto T. Gastric emptying time after breakfast in healthy adult volunteers using ultrasonography. | Anesth. 2019;33(6):697-700.

24. Bolondi L, Bortolotti M, Santi V, Calletti T, Gaiani S, Labò G. Measurement of gastric emptying time by real-time ultrasonography. Gastroenterology. 1985;89(4):752-9.

25. Van de Putte P, Perlas A. Ultrasound assessment of gastric content and volume. Br J Anaesth. 2014;113(1):12-22.

26. Bolondi L. Correlation between scintigraphic and ultrasonographic assessment of gastric emptying. Gastroenterology. 1986;90:1349. 